DOI https://doi.org/10.15589/znp2019.4(478).6 УДК 330.341 .1

\title{
SOCIAL INVESTMENT AS A SOURCE OF SOCIAL CAPITAL ACCUMULATION
}

\section{СОЦІАЛЬНЕ ІНВЕСТУВАННЯ ЯК ДЖЕРЕЛО НАГРОМАДЖЕННЯ СОЦІАЛЬНОГО КАПІТАЛУ}

\author{
Inna I. Nafus, \\ inafus199113@ukr.net \\ ORCID: 0000-0002-3211-2504
}

\author{
I. I. Haфyc, \\ PhD-студент
}

\author{
Yuri Fedkovich National University of Chernivtsi, Chernivtsi \\ Чернівецький національний університет імені Юрія Федьковича, м. Чернівці
}

\begin{abstract}
The article defines the types and features of social investment and the possibility of focusing social investment on the formation of social capital as an economic resource. Possible socio-economic results of using social investments at different levels of functioning of the economy are substantiated. The methodology of micro- and macroeconomic analysis, interdisciplinary and institutional approaches have been applied. The object of the study is the socio-economic relations that determine the content, patterns and conditions of accumulation of social capital. The subject of the study is the role of social investment in the accumulation of social capital at different levels of the functioning of the economy.

The characteristic features of social capital as an economic resource are defined. The directions of influence of social investments on the formation of social capital at different levels of functioning of the economy are substantiated. These include: at the nanoscale - mitigating social problems, reducing the burden on local budgets to address social problems, increasing confidence, addressing social problems of small groups and local communities; at the micro level, the transformation of social values; formation of corporate consciousness; increasing mutual commitments and responsibilities, developing social standards for doing business, democratizing management approaches, improving corporate reputation and attracting new customers; at the metro level - consolidation and improvement of the effective use of existing social networks, common norms and beliefs, partnerships, trust in institutions of different levels, perception of universally established values, public solidarity and cohesion; at the macro level - the formation of a new organizational culture of society that takes into account the innovations of the political, economic and spiritual life of the society, public-private partnership, social responsibility of the state, business, civil society; at a megawatt - it is the creation of associations of venture philanthropy, social investment exchanges in different countries, networks of social intermediaries and more.

The objective necessity and ability to use social investment as a source of social capital formation at different levels of functioning of the economy have been proved.
\end{abstract}

Key words: socialization of the economy; social investment (SI); social capital (IC); levels of social capital formation; Corporate Social Responsibility (CSR); public-private partnership (PPP).

Анотація. У цій статті визначено види та особливості соціального інвестування й можливості спрямованості соціальних інвестицій на формування соціального капіталу як економічного ресурсу. Обгрунтовано можливі соціально-економічні результати використання соціальних інвестицій на різних рівнях функціонування економіки. Застосовано методологію мікро- та макроекономічного аналізу, міждисциплінарний та інституціональний підходи. Об'єктом дослідження є соціально-економічні відносини, що визначають зміст, закономірності та умови нагромадження соціального капіталу. Предмет дослідження - роль соціального інвестування в нагромадженні соціального капіталу на різних рівнях функціонування економіки.

Визначено характерні особливості соціального капіталу як економічного ресурсу. Обгрунтовано напрями впливу соціальних інвестицій на формування соціального капіталу на різних рівнях функціонування економіки. До таких напрямів зараховано: на нанорівні - пом'якшення соціальних проблем, зниження навантаження на місцеві бюджети у вирішення суспільних проблем, приріст довіри, вирішення соціальних проблем малих груп та місцевих громад; на мікрорівні - трансформацію суспільних цінностей; формування корпоративної свідомості; зростання взаємних зобов'язань і відповідальності, формування соціальних стандартів ведення бізнесу, демократизацію підходів до управління, поліпшення репутації підприємств та можливості залученості нових клієнтів; на метарівні - закріплення та підвищення ефективності використання діючих соціальних мереж, спільних норм і переконань, партнерських стосунків, довіри до установ різного рівня, сприйняття 
загальновстановлених цінностей, суспільну солідарність та згуртованість; на макрорівні - формування нової організаційної культури суспільства, що враховує інновації політичного, економічного і духовного життя суспільства, державно-приватне партнерство, соціальну відповідальність держави, бізнесу, громадянського суспільства; на мегарівні - це створення асоціацій венчурної філантропії, бірж соціальних інвестицій у різних країнах, мереж соціальних посередників тощо.

Доведено об'єктивну необхідність та можливість використання соціальних інвестицій як джерела формування соціального капіталу на різних рівнях функціонування економіки.

Ключові слова: соціалізація економіки; соціальні інвестиції (CI); соціальний капітал (СК); рівні формування соціального капіталу; корпоративна соціальна відповідальність (КСВ); державно-приватне партнерство (ДПП).

\section{ПОСТАНОВКА ЗАДАЧІ}

В Україні як у політиці управління, так і в практиці господарювання розв'язання соціальних проблем, як правило, відкладається за «залишковим» принципом на майбутні часи. Соціальне інвестування розглядається як певний аспект соціалізації бізнесу, а соціальний капітал - як характеристика взаємовідносин (переважно в негативному розумінні, як атрибут корупційних зв'язків). Однак, як свідчить практика соціалізації економіки розвинених країн, проблематика інвестування в соціальний капітал актуалізує такі важливі проблеми функціонування економічних відносин: відсутність довіри в економічній взаємодіі; дефіцит сприятливих норм функціонування бізнесвідносин; високі трансакційні витрати; поширеність опортуністичних практик економічної поведінки; відсутність ефективних механізмів економічних інтересів держави, бізнесу, громадянського суспільства. Зазначені проблеми безпосередньо пов'язані з масштабами нагромадження та ефективністю використання СК на різних рівнях функціонування економіки.

\section{АНАЛІЗ ОСТАННІХ ДОСЛІДЖЕНЬ І ПУБЛІКАЦЙ}

В Україні різні аспекти соціального капіталу, що характеризують його сутність, функції, структуру та значення в економічного розвитку, досліджують такі науковці, як А. Бова, Б. Буркинський, Г. Волчкова, Н. Гавкалова, 3. Галушка, В. Геєць, М. Горожанкіна, О. Грішнова, Ю. Зайцев, Т. Заяць, Г. Коломієць, Е. Лібанова, М. Лесечко, О. Міночкіна, К. Немешкало, О. Новікова, В. Якобчук та ін. Процесам нагромадження соціального капіталу у формі неформальних механізмів соціального регулювання економічних відносин, зростання довіри, формування ринкових цінностей, розширення соціальних мереж значна увага приділяється фахівцями Інституту економіки та прогнозування НАН України, Інституту демографії та соціальних досліджень ім. М.В. Птухи НАН України, Інституту соціології НАН України, аналітичного Центру Разумкова. Проблеми соціального інвестування актуалізуються в працях А. Загороднього, А. Зінченко, І. Лазаренко, Г. Партина, М. Саприкіної, О. Сотули, Н. Удод, В. Шаповал та інших дослідників.

\section{ВІДОКРЕМЛЕННЯ НЕ ВИРІШЕНИХ РАНІШЕ ЧАСТИН ЗАГАЛЬНОЇ ПРОБЛЕМИ}

Разом із тим у наведених дослідженнях не вистачає наукового обгрунтування можливостей нагромадження соціального капіталу як економічного ресурсу на різних рівнях функціонування економіки на основі соціального інвестування. 3 нашого погляду, розробка теоретичних та прикладних засад нагромадження СК на основі соціального інвестування має служити теоретичним підгрунтям для удосконалення та застосування сучасних соціалізованих практик регулювання соціально-економічних відносин у державному управлінні, у бізнесі, міжсуб'єктних відносинах на різних рівнях господарювання.

Мета дослідження - визначити види та особливості соціального інвестування, можливості спрямованості соціальних інвестицій на формування соціального капіталу як економічного ресурсу та обгрунтування можливих соціально-економічних результатів його використання на різних рівнях функціонування економіки.

\section{МЕТОДИ, ОБ'ЄКТ ТА ПРЕДМЕТ ДОСЛІДЖЕННЯ}

Міждисциплінарний підхід дав змогу визначити сутність, види та особливості соціального інвестування. Інституціональний аналіз застосовано при визначенні чинників впливу соціального інвестування на регулювання соціальних відносин та нагромадження СК на нано-, мікро-, мета і макро- і мегарівнях функціонування економіки.

Об'єктом дослідження є соціально-економічні відносини, що визначають зміст, закономірності та умови нагромадження соціального капіталу. Предметом дослідження є роль соціального інвестування в нагромадженні соціального капіталу на різних рівнях функціонування економіки.

\section{ОСНОВНИЙ МАТЕРІАЛ}

СК можна визначити як економічний нематеріальний ресурс, що формується як сукупність структурно оформлених соціальних відносин на різних рівнях функціонування економіки дякуючи соціальним мережам, довірі, цінностям і нормам взаємної поведінки та забезпечує його власникам доступ до різноманітних благ, а також додаткові можливості підвищувати 
ефективність колективної діяльності та отримувати економічні вигоди. Саме як економічний ресурс він має низку специфічних характеристик (рис. 1).

Нагромадження СК $є$ одним із найактуальніших завдань сталого розвитку сучасної економіки, а «...CI - одним з основних інструментів реалізації соціальних програм сучасних компаній. Вони мають забезпечувати певний ефект не лише інвестору (бізнесефект), але й тому, хто їх отримує (соціальний ефект): окремій особі, групі людей, місцевому співтовариству чи суспільству загалом (насамперед це підвищення рівня і якості життя людей шляхом задоволення їх матеріальних, духовних або соціальних потреб) [7].

СІ у СК мають місце на усіх рівнях господарювання, і на кожному із цих рівнів розрізняються інвестори та бенефіціари. На нанорівні СІ часто проявляються через благодійність. У благодійності важливе місце мають практики соціальної допомоги, які розрізняються за такими функціями: просвітницькі (надання інформації з приводу імовірних шляхів вирішення складної життєвої ситуації, адаптації до обставин, що склалися), ресурсні (матеріальні виплати), реабілітаційні (зокрема, медичні), комунікативні (юридичне, адміністративне, медичне представництво), культурно-дозвіллєві та інші [1]. У 2017 р. порівняно з 2010 p. Україна у світовому рейтингу благодійності піднялася на 60 позицій - до 90 місця. Благодійництво означає, що поступово формується СК, що, з одного боку, забезпечує статусну підтримку певних верств населення, а з іншого - згуртовує суспільство, передаючи норми взаємного спілкування та довіри.

На нанорівні CI можуть виступати також у формі соціального підприємництва - діяльності, спрямованої на вирішення або пом'якшення соціальних проблем інших громадян на умовах самоокупності (прибутковості), інноваційності та стійкості. Соціальне підприємництво є сучасним трендом соціалізації економічних відносин, реалізація принципів якого сприяє розв'язанню соціальних проблем окремих громадян чи їх груп, породжує нові підходи до ведення бізнесу, забезпечує формування усіх складників СК. Позитивні ефекти від діяльності соціальних підприємств - це «...допомога у подоланні соціальної ізольованості специфічних груп населення (інвалідів, психічно нездорових, безробітних та ін.); виявлення нових шляхів для реформування державних соціальних послуг; залучення громадян до участі у соціальних ініціативах, об'єднання громад навколо соціальних проблем; поява нових видів соціальних послуг, які залишаються поза увагою звичайного бізнесу у зв'язку з малоприбутковістю, непопулярністю, відсутністю належної професійної підготовки; більш ефективне використання наявних ресурсів регіону у вирішенні соціальних проблем; зниження навантаження на місцеві бюджети у вирішенні соціальних проблем» [5]. Соціальне підприємництво проявляється, насамперед, як цінність, що надається суспільству (громадянину, незахищеним верствам населення); у результаті CI у соціальне підприємництво суспільство набуває нових рис - зростає довіра до бізнесу, здійснюється статусна підтримка громадян; активізується громадянське суспільство; підвищується гармонійність стосунків, можливість узгодження інтересів, відбувається зростання емоційного інтелекту, поліпшення доступу до інформації через суспільні зв'язки та ін. В Україні соціальне підприємництво недостатньо поширене через відсутність досвіду, неприбутковість або низьку прибутковість, відсутність правової

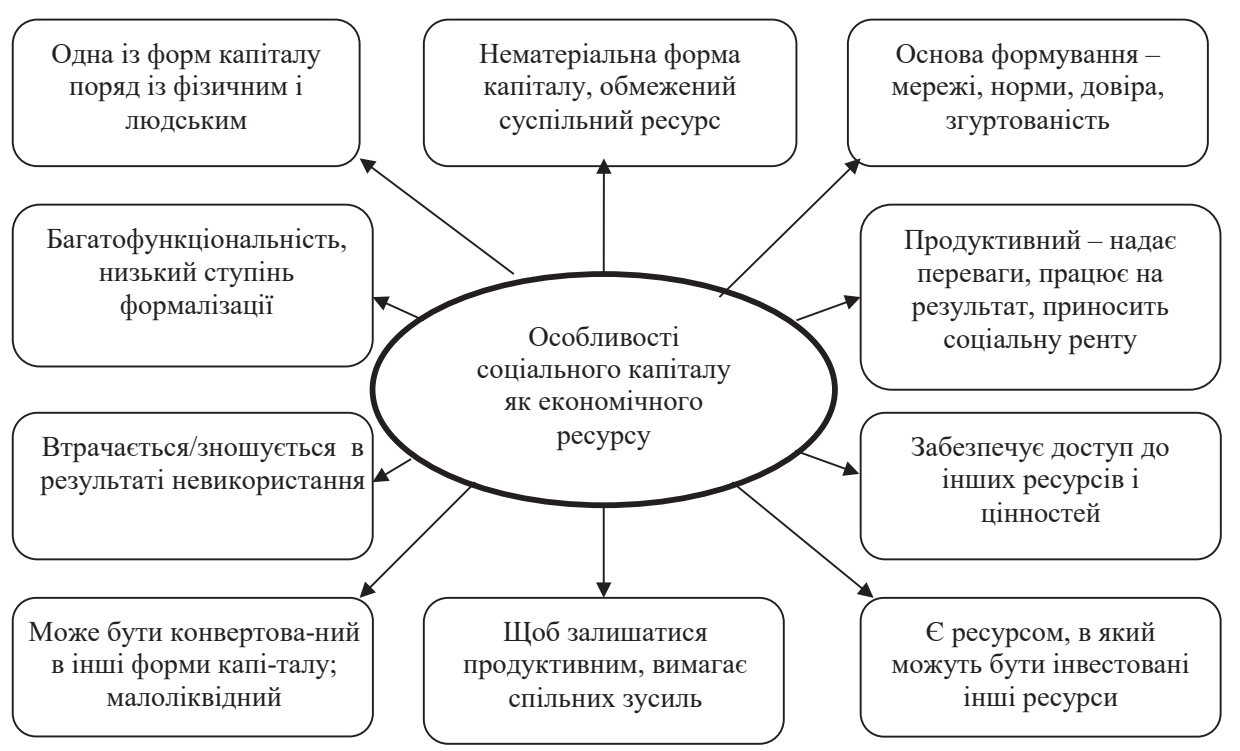

Рис. 1. Соціальний капітал як економічний ресурс Джерело: складено авторами 


\section{ЕКОНОМІКА ТА МЕНЕДЖМЕНТ № 4-2019}

підтримки, державних привілеїв чи співпраці з владою тощо.

На мікрорівні соціальні інвестиції стосуються здійснення заходів щодо соціальної відповідальності бізнесу, поліпшення корпоративної культури та підсилення ділової репутації підприємств. У результаті відбувається трансформація суспільних цінностей і норм, формуються неформальні економічні структури, що пов'язані між собою зростанням взаємних зобов'язань та відповідальності, починають складатися та дотримуються соціальні стандарти ведення бізнесу, виникають нові форми взаємодії у соціальних мережах, розвивається державно-приватне партнерство. На цьому рівні СК окремого працівника як особи, яка включена у соціальні зв'язки та соціальні мережі, визнає та підтримує певні норми і цінності, також $є$ результатом CI, його СК може бути конвертований у капітал підприємства. Вигоди роботодавця від використання СК працівника можуть мати різний характер. Це може бути доступ до ринкової інформації, що забезпечується через соціальні зв'язки працівника, доступ до певних соціальних зв'язків чи економічних ресурсів, переймання норм і цінностей, моделей поведінки, що забезпечує певний ступінь довіри в колективі.

Вітчизняний досвід також показує, що найбільш перспективною схемою побудови партнерських відносин в Україні в соціальній сфері $є$ концесійна форма ДПП, оскільки вона передбачає довгострокове партнерство, яке дає змогу сторонам здійснювати стратегічне планування своєї діяльності. Об'єкти ДПП в Україні у соціальній сфері - це: охорона здоров'я, заклади освіти, культури, спорту, ті, що використовуються для організації відпочинку й туризму. Перевагами ДПП у соціальній сфері в напрямі нагромадження СК можуть бути: індивідуальний підхід до соціальних програм у регіоні; використання договірних підходів до ціноутворення; змога субсидіювати споживачів соціальних послуг, а не їх виробників, особливо в освіті та охороні здоров'я; змога здійснювати фінансування соціальних програм ДПП із приватних джерел; удосконалення законодавчо-нормативного забезпечення CI; змога розробляти механізм діалогу та публічного обговорення соціальних проектів тощо.

CI сфери бізнесу, що стосуються заходів КСВ, реалізуються через такі види діяльності: спрямованість на дотримання екологічних норм виробництва, гарантування безпеки якості товарів для споживачів; використання безпечних технологій виробництва i збуту продукції; розвиток людських ресурсів та трудових відносин, соціальний захист робітників компанії; ведення відкритого та прозорого діалогу між приватним та державним секторами для покращення політики і норм, що регулюють такі сфери, як працевлаштування, природоохоронні норми та інше; заходи 3 охорони навколишнього середовища та екологічної безпеки виробництва; участь у розв'язанні актуальних проблем у сфері зайнятості, боротьбі з бідністю, підтримці закладів освіти, медицини; впровадження соціальних інновацій та ін. [6, с. 145]. Ми розглядаємо кілька концепцій, які підтверджують роль СВБ як чинника нагромадження соціального капіталу [2].

Дослідження практики КСВ в Україні свідчить про те, що для більшості приватних компаній КСВ це політика розвитку і поліпшення умов праці персоналу, для третини з них - захист і підтримка споживачів та інвестиції в розвиток регіону. Розвиток і поліпшення умов праці персоналу вважають сутністю КСВ 75,5\% представників бізнесу, захист і підтримка споживачів - 34\%, інвестиції в розвиток регіону - 34\%, допомога воїнам АТО та мешканцям зони АТО - $28 \%$, благодійна допомога - $28 \%$, участь у розробці реформ та законів - 27\%, здійснення екологічних проектів $26,5 \%$, боротьба 3 корупцією - 23\% [4]. Поступово КСВ сучасних компаній втілюється у таких напрямах: врегулювання правової та етичної відповідності компанії сучасним тенденціям розвитку економіки і суспільства; упровадження неформальних підходів до соціальної відповідальності компанії, формуванні підходів та принципів корпоративної культури. СI забезпечують ефективне вирішення таких спрямованих у зовнішнє середовище соціальних проблем, як благодійність, охорона навколишнього середовища, розвиток місцевої громади, а також спрямованих на розвиток самої організації заходів щодо розвитку персоналу, охорони здоров'я та безпека праці, соціальної безпеки працюючих.

Наведене дослідження продемонструвало низький рівень діалогу компаній зі стейкхолдерами в генеруванні ідей для розробки та впровадження програм/ заходів із КСВ, оскільки головним джерелом ідей $є$ керівництво та співробітники компаній. Зовнішні джерела ідей для програм/заходів із КСВ (звернення місцевих органів влади, громадських організацій та пропозиції бізнес-партнерів) не відіграють значної ролі в розробці програм/заходів із КСВ.

Під впливом CI соціальний та репутаційний капітал компанії формується як капіталізована ринкова вартість, створена в результаті встановлення та дотримання високих соціальних стандартів і етичних норм поведінки працівників, менеджерів і власників підприємства, високої ділової репутації, існування довіри і готовності співпрацювати та ділитися інформацією як всередині підприємства, так і між групами зацікавлених осіб (стейкхолдерів) задля підвищення індивідуального і колективного добробуту. Отже, CK, заснований на СI, має нематеріальну основу, формується і функціонує при мережевій взаємодії підприємств із партнерами, органами місцевого самоврядування, громадськими організаціями та характеризується «... рівнем взаємної довіри; стратегічною спрямованістю, залежить від впливу внутрішньо- 
організаційних та зовнішніх економічних, політичних, конкурентних, соціокультурних та інших чинників; сприяє підвищенню стабільності та ефективності підприємницької діяльності і зростанню конкурентоспроможності підприємства» [3].

На мезорівні СІ виступають завданням і функцією як бізнесових структур, так і органів місцевого управління та самоврядування. Вони втілюються у ДПП, програмах соціального партнерства бізнесу і влади 3 громадськими і професійними об'єднаннями, CI у громаду (партнерські соціально орієнтовані проекти бізнесу, місцевої влади і некомерційних організацій), розробці соціальних складових частин стратегій соціально-економічного розвитку регіону та передбачають закріплення та підвищення ефективності використання діючих соціальних мереж, спільних норм і переконань, партнерських стосунків, довіри до установ різного рівня, сприйняття загальновстановлених цінностей, суспільну солідарність та згуртованість.

Для досягнення ефективності взаємодії бізнесу та влади у процесі реалізації соціально інвестиційних проектів можуть використовуватися такі моделі: пайова участь у фінансуванні соціальних проектів; пайова участь держави у статутному капіталі лізингових компаній, що здійснюють закупівлю нової техніки; надання з боку держави гарантій приватному сектору, якщо його інвестиції мають соціальну спрямованість; просування приватних проектів, спрямованих на реалізацію державних інтересів на створенрму державою майданчику для пошуку та взаємодії з іноземними партнерами, надання інформаційної та політичної підтримки в цій взаємодії.

Спрямованість CI на формування СК на мезорівні реалізується таким чином через: закріплення та підвищення ефективності використання діючих соціальних мереж, спільних норм і переконань; партнерські стосунки, довіру до установ різного рівня; сприйняття загальновстановлених цінностей, суспільну солідарність та згуртованість; сприяння поширенню інформації та довіри, діловим операціям і економічному зростанню. Ї̈̈ соціально-економічним результатом виступають інтеграція СК, що складається на різних рівнях, взаємна довіра, виникнення нових форм контролю за використанням ресурсів, об'єктів інфраструктури, грошових коштів у зв'язку 3 перетворенням відносин власності, формуванням мережевих структур бізнесового і небізнесового спрямування.

На макроекономічному рівні CI мають бути спрямовані на створення державою сприятливих умов для самоорганізації та взаємодії в суспільстві. Спрямованість державних СI має передбачати формування нової організаційної культури суспільства, що враховує інновації політичного, економічного і духовного життя суспільства. Це система формальних та неформальних правил, що формують механізми координації поведінки, розвиток громадянського суспільства, різних форм самоорганізації населення, забезпечують соціальний діалог, державно-приватне партнерство, соціальну відповідальність держави, бізнесу, громадянського суспільства. Має відбутися формування сучасних суспільних інститутів, які санкціонують норми і структуру соціальних відносин, функції державних структур, діапазон прав і обов'язків індивідів, форми координації суспільних процесів. У цьому напрямі розробка Стратегій соціально-економічного розвитку на макро- і на мезорівнях виступає важливим елементом врядування та визначає місію й пріоритетні напрями розвитку, а також способи їх реалізації.

У «Стратегії сталого розвитку України до 2020 року» зазначено важливі соціальні завдання (подолання бідності, скорочення нерівності, забезпечення охорони громадського здоров'я, благополуччя, перехід до моделей збалансованого споживання i виробництва), але не передбачалося конкретних механізмів реалізації цих завдань. У «Стратегії впровадження моделі збалансованого розвитку України до 2030 року» вже передбачено конкретні механізми суспільного договору: спільність інтересів, інтеграція зусиль держави та бізнесу через державно-приватне партнерство, верховенство права, публічність та прозорість, всезагальна участь і персональна відповідальність кожного, патріотизм і толерантність, свобода інформації, узгодженість діяльності інститутів державної влади та управління, професіоналізм у виконанні всіма членами суспільства своїх зобов'язань, результативність та ефективність, соціальна справедливість у забезпеченні рівності прав і можливостей, стратегічне бачення). Вони формально закріплюють умови нагромадження СК.

На мегаекономічному рівні соціалізація економіки та соціальне інвестування перетворилися на глобальну тенденцію розвитку світової економіки. Глобальна мережа соціальних інвесторів (Global Impact Investment Network (GIIN)) дає значні темпи зростання CI. Відповідно, відбувається скорочення соціальних видатків із державних бюджетів, уряди частково передають свої соціальні функції на аутсорсинг приватним компаніям, які можуть забезпечити більшу ефективність використання коштів і забезпечити вищу якість соціальних послуг. Як показує досвід соціально розвинених країн, у державній соціальній політиці принцип «оплата за соціальний результат» дедалі частіше приходить на зміну принципу «оплата за послугу». Однією з нових перспективних форм соціального інвестування стала в останнє десятиліття венчурна філантропія. Інструменти, використовувані венчурними фондами, дедалі частіше застосовуються до соціальних стартапів. Подібний підхід дає змогу надати початківцям підприємствам загальну операційну і менторську підтримку, допомогу в розробці бізнес-моделі, стратегії розвитку, а також наймі пер- 
соналу. У США працюють такі організації венчурної філантропії, як New Profit Inc, Social Venture Partners (на фото), Venture Philanthropy Partners, SV2 and Draper, Richards, Kaplan. Європейська Асоціація венчурної філантропії налічує понад 170 членів, Азіатська мережа - більше 160 членів із 28 країн, а Японія створила в 2013 р. свій перший національний фонд венчурної філантропії JVFP, спільно керований Фондом Nippon і організацією Social Investment Partners.

Ще одним інструментом, що сприяє розвитку соціальних інвестицій і підвищує їх доступність, є соціальні біржі, найстарішою і найбільш авторитетною 3 яких є Азіатська біржа соціальних інвестицій (IIX), створена в 2005 р. У 2013 р. до їі складу увійшла Біржа Соціальних інвестицій у Південній Африці Nexii. У 2013 р. почала роботу Соціальна біржа в Лондоні (SSE), нині ведеться робота зі створення аналогічної біржі в Берліні. Існує соціальна біржа і в Канаді (SVX).

Держава може значним чином вплинути на сферу соціальних інвестицій, якщо відмовиться в політиці державних закупівель від стратегії «плати за послуги» (найчастіше за зумовленою ціною) на користь практики «плати за результат». Для реалізації цього підходу використовуються, насамперед, соціальні облігації. Така практика стимулює інновації в соціальній сфері ефективніше багатьох інших інструментів, адже, як уже згадувалося вище, в разі недосягнення поставлених соціальних цілей оплата не провадиться. Це стимулює соціальні організації до пошуку найефективніших методів і моделей роботи.

\section{ОБГОВОРЕННЯ ОТРИМАНИХ РЕЗУЛЬТАТІВ}

Узагальнюючи наведені підходи до визначення сутності й особливостей соціального інвестування та напрямів його впливу на формування СК, зауважимо необхідність визначення можливого соціально-економічного результату цього впливу. 3 нашого погляду, його можна виділити на кожному з рівнів функціонування економічних відносин:

- на нанорівні - статусна підтримка громадян, активізація громадянського суспільства, гармоній- ність стосунків, узгодження інтересів, зростання емоційного інтелекту, поліпшення доступу до інформації через суспільні зв'язки;

- $\quad$ на мікрорівні - працевлаштування, доступ до соціальних послуг, поліпшення умов праці, розвиток організаційної культури (норми, цінності, правила ведення переговорів, укладання угод тощо), етична відповідність компанії тенденціям розвитку суспільства й економіки, зростання довіри в суспільстві;

- $\quad$ на метарівні - інтеграція СК, що складається на різних рівнях, взаємна довіра, виникнення нових форм контролю за використанням ресурсів, об'єктів інфраструктури, грошових коштів у зв'язку з перетворенням відносин власності, формуванню мережевих структур бізнесового і небізнесового спрямування;

- на макрорівні - формування сучасних суспільних інститутів, які санкціонують норми і структуру соціальних відносин, функції державних структур, діапазон прав і обов'язків індивідів, форми координації суспільних процесів;

- $\quad$ на мегарівні - формування глобального соціального капіталу, розвиток ринку соціальних інвестицій тощо.

\section{ВИСНОВКИ}

Соціальне інвестування виступає джерелом і наслідком функціонування СК на різних рівнях господарювання. На кожному з рівнів розрізняються види та особливості соціального інвестування, їхня спрямованість на формування СК та можливі соціально-економічні результати. СІ впливають на нагромадження усіх складових частин СК (довіру, норми, цінності, мережі). На кожному з вищих рівнів функціонування економіки CI охоплюють ширше коло інвесторів - від окремих осіб до глобальної мережі соціальних інвесторів та формування ринку соціальних інвестицій. Головним результатом виступають інтеграція СК та формування сучасних суспільних інститутів, які санкціонують норми і структуру соціальних відносин, функції державних структур, діапазон прав і обов'язків індивідів, форми координації суспільних процесів.

\section{REFERENCES}

[1] Lazarenko, I. S. (2016) Konvertaciya social'nogo kapitalu u praktiki social'noï dopomogi [Conversion of social capital into social assistance practices] Visnik NTUU «KPI». Politologiya. Sociologiya. Pravo. Vipusk 1/2 (29/30). Retrieved from: http://ela.kpi.ua/bitstream/123456789/24865/1/VPSP2016-1-258-64.pdf.

[2] Nafus, I. I. (2017) Social'na vidpovidal'nist' biznesu yak umova nagromadzhennya social'nogo kapitalu [Social responsibility of business as a condition of accumulation of social capital]. International Scientific Conference The Modern Trends in the Development of Business Social Responsibility: Conference Proceedings, May 19th, Lisbon, Portugal: Baltija Publishing. 292 p. Pp. 14-17. Retrieved from: http://skorobogatova.edu.kpi.ua/wp-content/uploads/2017/08/Portugalyya-Lysabonmaj-2017.pdf

[3] Partin, G. O., Zagorodnij, A. G, Zayac', N. I.(2019) Social'no-reputacijnij kapital pidpriemstva: sutnist', skladovi, ocinyuvannya [Social and reputational capital of the enterprise: nature, components, valuation]. Visnik agrarnoï nauki Prichornomor'ya. Vip. 1. DOI: 10.31521/2313-092X/2019-1 (101). S. 10-18.

[4] Rozvitok KSV v Ukraini 2010-2018 [Development of Corporate Social Responsibility in Ukraine 2010-2018]. Retrieved from: http://csr-ua.info/csr-ukraine/wp-content/uploads/2018/10/CSR_2017_reserch-1.pdf 8.09.19. 
[5] Social'ne pidpricmnictvo v Ukraini [Social entrepreneurship in Ukraine]. Retrieved from: http://www.socialbusiness.in.ua/ index.php/baza-znan/bibliotekasotsialnoho-pidpryiemtsia/81-pro-sotsialne-pidpryiemnytstvo.

[6] Udod, N. M. (2014). Social'nij kapital mizhnarodnogo biznesu [Social capital of international business]. «Molodij vchenij» № 12 (15), gruden’. Pp. 144-148.

[7] Shapoval, V. M., Shapoval, I. A. Social'ni investiciï yak instrument realizaciï social'nih program suchasnih kompanij [Social investment as a tool for implementing social programs of modern companies]. Retrieved from: http://ir.nmu.org.ua/bitstream/ handle/123456789/147366/7881.pdf?sequence=1\&isAllowed=y

\section{СПИСОК ВИКОРИСТАНОЇ ЛІТЕРАТУРИ}

[1] Лазаренко, I. С. (2016). Конвертація соціального капіталу у практики соціальної допомоги. Вісник НТУУ «КПI». Політологія. Соиіологія. Право. Випуск 1/2 (29/30). URL: http://ela.kpi.ua/bitstream/123456789/24865/1/VPSP2016-1258-64.pdf

[2] Нафус, І. І. Соціальна відповідальність бізнесу як умова нагромадження соціального капіталу. International Scientific Conference The Modern Trends in the Development of Business Social Responsibility: Conference Proceedings, May 19th, 2017. Lisbon, Portugal: Baltija Publishing. 292 p. P. 14-17. URL http://skorobogatova.edu.kpi.ua/wp-content/ uploads/2017/08/Portugalyya-Lysabon-maj-2017.pdf

[3] Партин, Г. О., Загородній, А. Г, Заяць, Н. І. (2019) Соціально-репутаційний капітал підприємства: сутність, складові, оцінювання. Вісник аграрної науки Причорномор'я. Вип. 1. DOI: 10.31521/2313-092X/2019-1 (101). С. 10-18.

[4] Розвиток Корпоративної соціальної відповідальності в Україні 2010-2018. URL: http://csr-ua.info/csr-ukraine/wpcontent/uploads/2018/10/CSR_2017_reserch-1.pdf 8.09.19.

[5] Соціальне підприємництво в Україні. URL: http://www.socialbusiness.in.ua/index.php/baza-znan/bibliotekasotsialnohopidpryiemtsia/81-pro-sotsialne-pidpryiemnytstvo .

[6] Удод, Н. М. (2014) Соціальний капітал міжнародного бізнесу. Молодий вчений. № 12 (15). Грудень. С. 144-148.

[7] Шаповал, В. М., Шаповал, I. А. Соціальні інвестиції як інструмент реалізації соціальних програм сучасних компаній. URL: http://ir.nmu.org.ua/bitstream/handle/123456789/147366/7881.pdf?sequence=1\&isAllowed=y 